Managing human-wildlife conflict and coexistence is a field of continuous learning that requires collaborative processes tailored to social and cultural contexts. To this end the IUCN Species Survival Commission Human-Wildlife Conflict Task Force has published an IUCN Position Statement on the Management of Human-Wildlife Conflict, urging governments, NGOs, researchers, practitioners, community leaders, environmental agencies and others to ensure that efforts to manage human-wildlife conflicts are pursued through wellinformed, holistic and collaborative processes that take into account underlying social, cultural and economic contexts.

The statement outlines the typical characteristics and underlying dimensions of these conflicts and proposes five key considerations to guide efforts promoting humanwildlife coexistence: (1) interventions that focus only on reducing damage are not transferable from one case to another, (2) poorly informed human-wildlife conflict mitigation attempts can exacerbate the situation, (3) context awareness and understanding of social and political backgrounds are crucial, (4) conflict mitigation and damage reduction interventions must be designed and managed collaboratively, and (5) long-term solutions must incorporate landscape-scale ecological, economic and physical patterns.

Building on this, the Task Force is developing detailed practical guidelines to assist practitioners, researchers, communities, and decision makers in navigating humanwildlife interactions. The IUCN Species Survival Commission Guidelines on the Management of Human-Wildlife Conflict and Coexistence, which provide comprehensive practical advice, will be piloted in late 2021 with conservation projects around the globe.

The IUCN Position Statement is available in four languages at iucn.org/theme/species/publications/policies-andposition-statements.

AlEXANDRA ZIMMERMANN (Do orcid.org/0000-0002-4371-3997) and JAMES STEVENS IUCN Species Survival Commission Human-Wildlife Conflict Task Force, Oxford, UK E-mail alex.zimmermann@ssc.iucn.org

This is an Open Access article, distributed under the terms of the Creative Commons Attribution licence CC BY 4.0.

\section{Conserving Dialium travancoricum, a Critically Endangered endemic tree}

Dialium travancoricum Bourd., an evergreen tree of the family Leguminosae (Dialioideae), endemic to the southern Western Ghats of Kerala, India, is the sole representative of its genus in India. This species was first collected by T.F. Bourdillon in 1898 in Ponmudi, Thiruvananthapuram district, and later from Aryankavu, Kollam district. The species had not been recorded since then and there was no ex situ conservation collection. The species was categorized as
Indeterminate and Possibly Extinct in the Red Data Book of Indian Plants in 1990, categorized as Critically Endangered on the IUCN Red List in 1998, and included in the national priority list of threatened plants in 2005.

While surveying for the rare tree Buchanania barberi in Ponmudi and Aryankavu during August 2019-March 2021, with support from The Mohamed Bin Zayed Species Conservation Fund (grant no. 180519970), we located one flowering individual of D. travancoricum in the evergreen tropical rainforest of Ponmudi, at $490 \mathrm{~m}$ altitude. We did not locate the species in Aryankavu. We conclude that the global population is small, with $<50$ mature individuals in an area of $<_{1} \mathrm{~km}^{2}$, and recommend that it continues to be categorized as Critically Endangered, but based on criteria B2ab(iii,v);D. Information from local people suggested that the potential threats to the species are: (1) habitat destruction caused by road construction, (2) increasing tourism in Ponmudi (a hill station), (3) low fruit set despite a high level of flowering, (4) few seedlings, and (5) former consumption of its fruits as a tamarind substitute (it is known locally as hill tamarind or Malampuli).

Action is required for the protection of this rare species. At Jawaharlal Nehru Tropical Botanic Garden and Research Institute seed germination and seedling establishment experiments are being carried out on seeds collected from Ponmudi, and trials are underway to raise seedlings using tissue culture. Further surveys across Ponmudi and Aryankavu are required, to determine if there are more individuals and, if so, to collect additional seeds for ex situ conservation.

AnURag DHYANi (ㅁorcid.org/0000-0003-0852-6237),

S. SuRESH, E.S. SANTHOSH KuMAR, S.M. SHAREEF and

R. PRAKASHKUMAR Jawaharlal Nehru Tropical Botanic Garden and Research Institute, Thiruvananthapuram, Kerala, India E-mail anuragdhyani@gmail.com

This is an Open Access article, distributed under the terms of the Creative Commons Attribution licence CC BY 4.0.

\section{New guidelines allow companies to plan and monitor biodiversity performance at the corporate level}

Businesses are striving to address their impacts on the environment and enhance their sustainability, but many find biodiversity daunting to deal with. Numerous indicators and metrics have been designed for businesses to measure corporate-level biodiversity performance, but none covers all types of business operations in all biomes. To address these challenges, in March 2021 IUCN published Guidelines for Planning and Monitoring Corporate Biodiversity Performance (P.J. Stephenson \& G. Carbone, 2021, dx. doi.org/10.2305/IUCN.CH.2021.05.en). The guidelines take 
lessons learnt from conservation science, practice and project management and translate them into a business context.

The guidelines propose a four-stage approach to develop a corporate-level biodiversity strategic plan: (1) identifying priority pressures and dependencies across company operations and supply chains, and the most important species, habitats and ecosystem services to protect; (2) defining company ambitions through a vision, goals, objectives and strategies; (3) choosing scalable, linked indicators to monitor delivery of company ambitions; and (4) implementing strategies, collecting data against a monitoring plan, and using and sharing data to facilitate adaptive management.

A key element is the pressure-state-response-benefit indicator model, which has become central to biodiversity monitoring for conservation projects and the Sustainable Development Goals. This model allows companies to measure progress along their theories of change and to demonstrate how their actions lead to outcomes and impacts. A unique feature of the IUCN approach is that it encourages companies to name the species, habitats and ecosystem services they will focus on, a level of specificity that will ultimately enhance the feasibility and measurability of their ambitions and the quality of their monitoring. The guidelines also act as a toolkit by explaining how existing business guidelines, standards and tools can be applied in the different stages of developing and implementing a corporate-level biodiversity strategic plan.

This work was a unique collaboration between the IUCN Species Survival Commission Species Monitoring Specialist Group, the IUCN Global Business and Biodiversity Programme, and companies from various sectors, especially Alcoa, Boskalis and Nespresso, who helped test and shape the guidelines. IUCN now encourages other companies to work with it to roll out and further test the guidelines. It is hoped this simple, stepwise process will encourage more companies to engage with nature and to see that doing so is less daunting than they thought.

\section{P.J. STEPHENSON (@ orcid.org/0000-0002-0087-466X) IUCN} Species Survival Commission Species Monitoring Specialist Group, Laboratory for Conservation Biology, Department of Ecology \& Evolution, University of Lausanne, Lausanne, Switzerland.E-mail stephensonpj@gmail.com

\section{GiUlia Carbone Global Business and Biodiversity Programme, IUCN, Gland, Switzerland}

This is an Open Access article, distributed under the terms of the Creative Commons Attribution licence CC BY 4.0.

\section{Increasing knowledge of the world's trees}

The pace of publishing IUCN Red List assessments for trees has increased dramatically, with a total of 28,676 tree assessments, 19,087 of which were published during December 2018-December 2020. Trees comprise nearly one-third of all threatened species on the IUCN Red List, and, although it is valuable to have so many tree species assessed, it is alarming that so many are at risk of extinction. Assessments for the Global Tree Assessment were undertaken by botanists worldwide, coordinated by Botanic Gardens Conservation International and the IUCN Species Survival Commission Global Tree Specialist Group following a strategic approach set out in 2015 (Oryx, 49, 410-415).

A particular focus has been to prioritize assessments of endemic tree species of the most biodiverse countries, including Brazil, Colombia, Indonesia and Papua New Guinea, and the complete assessment of all 3,118 tree species of Madagascar, of which 2,904 (93\%) are endemic. The latter was a collaborative effort involving Kew Madagascar Conservation Centre, Missouri Botanical Garden Madagascar Program, the University of Antananarivo, the IUCN Species Survival Commission Madagascar Plant Specialist Group, and other botanists. Priorities for conservation have been identified, and $63 \%$ of Madagascar's endemic trees are considered threatened with extinction.

In addition to the published IUCN Red List assessments, all other tree species now have either an IUCN Red List assessment awaiting formal review, a provisional assessment or a published national or regional Red List assessment. For the first time we have a comprehensive global overview of the status of trees and of each individual species. Data already published indicate that at least $26 \%$ of the world's 58,500 tree species are threatened with extinction. The target now is to ensure that all tree species have an up-to-date assessment published by 2023 .

In the meantime, the priority is to scale up conservation action for those tree species we know are threatened with extinction. A combination of ex situ and in situ approaches will be employed, with major efforts to incorporate threatened trees into ecological restoration and tree planting initiatives.

MALIN RIVERS (๑ orcid.org/0000-0001-9690-1353) and EMILY BEECH (๑ orcid.org/0000-0002-1107-254X) Botanic Gardens Conservation International, Richmond, Surrey, UK.E-mailmalin.rivers@bgci.org

SARA OLDFIELD (@ orcid.org/0000-0003-3706-5986) IUCN Species Survival Commission Global Tree Specialist Group, Cambridge, UK

This is an Open Access article, distributed under the terms of the Creative Commons Attribution licence CC BY 4.0 .

\section{0th Critically Endangered Jamaican rock iguana released into the wild}

Caribbean rock iguanas Cyclura spp. are categorized as threatened on the IUCN Red List, with the endemic Jamaican rock iguana C. collei categorized as Critically 